\title{
ANALISIS PENILAIAN TINGKAT KESEHATAN KOPERASI SYARIAH DALAM UPAYA MENINGKATKAN KINERJA DI KOPERASI AS-SAKINAH SIDOARJO
}

\author{
Siti Mas'ula, Renny Oktafia \\ Fakultas Agama Islam, Universitas Muhammadiyah Sidoarjo \\ Email Korespondensi: sitimasula740@gmail.com
}

\begin{abstract}
Financial Institutions are an important part in economic development in Indonesia, the existence of cooperatives is expected to realize the welfare of the community with the principle of helping. Considering, most indonesians are majority Muslim. However, in practice, cooperatives that develop today still use conventional systems, where in the view of the public there is still usury and is considered not in accordance with sharia principles. To make the operational principles of cooperatives in accordance with sharia principles, a Sharia Cooperative or Baitul Mal Wa Tamwil (BMT) was formed. The development of Sharia Cooperatives is very good in Indonesia. Based on data from the Ministry of Cooperatives and SMEs, the number of Sharia Cooperative business units reached 150,223 units with a total of 1.4 million members. The capital alone reached Rp.968 billion and the outside capital rp.3.9 trillion with a business volume of Rp.5.2 trillion. The purpose of this study is to find out the assessment of health level as well as the impact of health level assessment in an effort to improve the performance of Sharia Cooperative As-Sakinah Sidoarjo. This study uses qualitative descriptive method with case study approach that aims to gain in-depth knowledge related to events or problems that occur. The results of this study show that overall, the level of health of Cooperative As-Sakinah Sidoarjo can be said to be good even though there are still problems or obstacles that occur. The assessment of the level of health of cooperatives is able to improve the performance of cooperatives to be better and continue to improve in order to improve the development of cooperatives in the future.
\end{abstract}

Keywords: Sharia Cooperative, The Level Of Health Cooperatives, The Performance Of Cooperatives

\section{PENDAHULUAN}

Lembaga keuangan sangat berkontribusi dalam pembangunan perekonomian di Indonesia. Adanya tingkat perkembangan ekonomi dengan basis syariah di Indonesia, lembaga keuangan khususnya koperasi berlomba-lomba dalam memberikan pembiayaan dalam bentuk pemberian pinjaman pada UMKM (Usaha MikrO, Kecil, dan Menengah) serta pada para anggota.

Koperasi diharapkan dapat membantu mensejahterakan masyarakat, mengurangi tingkat kesenjangan ekonomi, tingkat pengangguran, sekaligus mengurangi jumlah kemiskinan yang terdapat di Indonesia. Dalam lembaga koperasi terdapat asas kekeluargaan sekaligus mempunyai prinsip tolong menolong. Peran koperasi sangat penting di kehidupan masyarakat. Akan tetapi, dalam praktik kegiatan koperasi yang berkembang saat ini masih menggunakan sistem konvensional, sebuah sistem yang masih terdapat unsur riba dan tidak sesuai dengan syariat islam. Padahal, sebagian besar masyarakat Indonesia adalah mayoritas muslim. Maka dalam hal ini, perlua adanya perbaikan terkait prinsip operasional koperasi yang harus sesuai dengan syariat islam (Marlina \& Pratami, 2017).

Agar dapat memperbaiki prinsip tersebut, maka dibentuklah Koperasi Syariah atau BMT (Baitul Mal Wa Tamwil). Saat ini, banyak para penggerak koperasi yang sudah berinisiatif untuk mendirikan koperasi dengan berbasis syariah. Meskipun terkait jumlah koperasi di Indonesia masih sedikit, namun dalam perkembangan koperasi sangat berkembang dengan baik.

Perkembangan tersebut dapat diliat dari Data Kementrian Koperasi dan UKM, dari jumlah unit usaha Koperasi Syariah mencapai 150.233 unit dengan jumlah anggota koperasi sebesar 1,4 juta orang. Sedangkan modal sendiri koperasi sebesar Rp 968 miliar dan modal luar koperasi Rp 3,9 triliun. Sekaligus volume usaha 
koperasi yang mencapai $\mathrm{Rp} 5,2$ triliun (www.depkop.go.id).

Koperasi Syariah merupakan bidang usaha ekonomi yang sudah terorganisir secara baik dan berwatak sosial, dimana dalam kegiatan operasionalnya menerapkan prinsip-prinsip etika secara moral, harus memperhatikan halal atau haramnya sebuah usaha yang dijalankan sebagaimana yang sesuai dengan syariat islam yang diajarkan (Buchori, 2012).

Koperasi Syariah yang disebut dengan KSPPS (Koperasi Simpan Pinjam dan Pembiayaan Syariah) telah berkembang dan menjadi tempat bagi para anggota muslim yang membutuhkan sistem pengelolaan dengan berbasis syariah. Koperasi Syariah berlandaskan al-quran dan as-sunnah serta berasaskan kekeluargaan. Dalam Koperasi Syariah terdapat unsur tolong menolong (ta'awun) dan kerja sama (syirkah) menganjurkan saling tolong menolong untuk kebaikan, dan melarang tolong menolong yang menimbulkan dosa (Sofiani, 2014).

Prinsip Koperasi Syariah, menegakkan prinsipprinsip ekonomi islam. Dimana manusia diberi kebebasan dalam bermuamalah yang sesuai dengan ketentuan syariat islam, menjunjung tinggi keadilan dan menolak sistem bunga yang merugikan anggota. Sedangkan dalam melaksanakan kegiatanya didasarkan atas prinsip keanggotaan bersifat sukarela atau terbuka, dimana pada saat pengambilan keputusan dilakukan secara musyawarah dan konsisten, sistem pengelolaan yang professional, pembagian sisa hasil usaha yang merata (yang disesuaikan besar usaha masing-masing), jujur, amanah, dan mandiri (Marlina \& Pratami, 2017).

Kegiatan usaha yang terdapat dalam Koperasi Syariah adalah unit simpan pinjam dan pembiayaan. Pada unit simpan pinjam, koperasi bergerak dalam bidang penghimpunan dana dari para anggota, kemudian akan disalurkan kembali dalam bentuk pembiayan melalui pemberian pinjaman kepada anggota atau pelaku usaha mikro, kecil, dan menengah yang membutuhkan modal untuk pengembangan sebuah usaha (Nutri \& Wahyuningrum, 2019).

Hal ini, sesuai dengan fungsi yang melekat dari lembaga koperasi yaitu dapat memperkuat perekonomian masyarakat melalui pembiayaan mikro sekaligus membantu pemerintah dalam upaya mewujudkan pemerataan atau tingkat kesejahteraan masyarakat (Oktafia, 2017).

Salah satu Koperasi Syariah yang aktif menjalankan bidang usaha dalam bentuk simpan pinjam serta pembiayaan adalah Koperasi Syariah AsSakinah Sidoarjo, yang merupakan Pimpinan Wilayah Aisyiyah (PWA) Jawa Timur. Dalam koperasi tersebut mempunyai program Bina Usaha Ekonomi Keluarga
Aisyiyah. Koperasi ini didirikan pada tahun 1999 dan sudah berbadan hukum. Dimana awal berdirinya koperasi ini, anggota koperasi ada 25 anggota dari keluarga aisyiyah. Awal didirikan, pada saat itu aset koperasi sebesar Rp 15.000.000 yang diperoleh dari simpanan pokok tiap anggota Rp 25.000 dan simpanan wajib tiap anggota Rp 1000.

Perkembangan Koperasi As-Sakinah tahun 2019, secara keseluruhan kinerja koperasi mengalami peningkatan sampai pertengahan tahun, baik dalam bidang usaha, organisasi, administrasi keuangan, dan manajemen. Namun terdapat upaya untuk menjadi lebih baik sampai tahun selanjutnya, dikarenakan masih terdapat permasalahan yang muncul. Permasalahan tersebut yaitu banyaknya anggota yang mengundurkan diri, kurang tertib dalam proses pencatatan keluar masuknya barang sehingga sering kali mengalami kesulitan dalam perhitungan persediaan, bukti transaksi kurang lengkap dan tidak tertata rapi, serta terjadinya kredit macet.

Dari permasalahan tersebut akan berdampak pada tingkat kesehatan koperasi. Tinggi rendahnya tingkat kesehatan koperasi akan menentukan kelangsungan koperasi, apakah terus berkembang (active) atau justru tidak berkembang (non active) (Harto \& Amaliah, 2018). Dalam hal ini, lembaga koperasi perlu menjaga eksistensinya melalui peningkatan kinerja koperasi.

Kinerja merupakan kegiatan atau sebuah program kerja dimana dapat mewujudkan tujuan dari visi misi organisasi yang tertuang dalam perumusan skema strategi suatu organisasi (Listiadi \& Hastuti, 2020).

Untuk meningkatkan kinerja koperasi, baik dari segi kinerja keuangan maupun kelembagaan dan manajemen sangat diperlukan penilaian tingkat kesehatan koperasi. Adapun penilaian tingkat kesehatan koperasi dapat ditinjau dari 6 indikator yaitu:
a. Indikator Badan usaha aktif.
b. Indikator kinerja usaha yang semakin sehat.
c. Indikator kohesivitas dan partisipasi anggota.
d. Indikator orientasi kepada pelayanan anggota.
e. Indikator pelayanan terhadap masyarakat
f. Indikator terhadap pembangunan daerah.

Dengan kinerja koperasi yang baik akan memberikan pengaruh baik untuk perkembangan sebuah koperasi dimasa depan (Okfitasari \& Suyatno, 2018). Berdasarkan uraian permasalahan diatas, peneliti tertarik untuk melakukan penelitian dengan judul "Analisis Penilaian Tingkat Kesehatan Koperasi Syariah Dalam Upaya Meningkatkan Kinerja Di Koperasi As-Sakinah Sidoarjo".

\section{METODE PENELITIAN}

Jenis penelitian yang digunakan oleh peneliti dalam proses penelitian adalah metode penelitian 
kualitatif. Penelitian disajikan kedalam bentuk deskriptif yang sesuai dengan judul "Analisis Penilaian Tingkat Kesehatan Koperasi Syariah Dalam Upaya Meningkatkan Kinerja Di Koperasi As-Sakinah Sidoarjo". Dalam penelitian kualitatif bersifat tidak pasti dan masih terus berkembang seiring berjalannya waktu (Sugiyono, 2019).

Jenis data yang digunakan peneliti dalam melakukan penelitian adalah data primer maupun skunder, dimana yang diperoleh dari hasil proses wawancara secara langsung pada pengurus lembaga koperasi sekaligus website lembaga koperasi. Peneliti menggunakan metode kualitatif dengan pendekatan studi kasus, dimana penelitian dengan pendekatan studi kasus dapat dilakukan secara detail dan mendalam tentang peristiwa atau permasalahan pada sebuah lembaga (Eindrias \& Azizah, 2017).

Peneliti melakukan penelitian pada Koperasi Syariah yaitu Koperasi As-Sakinah Sidoarjo, bertempat di J1. Majapahit No. 28, Dusun Minggir, Larangan, Kecamatan Candi, Kabupaten Sidoarjo, Jawa Timur 61271. Penelitian ini dilakukan disatu tempat karena ingin mendapatkan hasil yang maksimal dari judul yang diteliti. Penelitian dilakukan dari bulan September sampai bulan Maret. Peneliti tertarik untuk mengangkat judul tersebut karena kinerja koperasi secara keseluruhan masih belum optimal dan masih terdapat permasalahan yang muncul, sehingga berdampak pada tingkat kesehatan koperasi.

Teknik pengumpulan data yang digunakan peneliti dalam melakukan penelitian adalah :

a. Observasi

Dalam penelitian ini, peneliti mengamati kinerja keseluruhan yang ada dalam lembaga koperasi. Dalam melakukan observasi, objek penelitian yang diamati oleh peneliti adalah place, activity atau cooperative performance. Jenis observasi yang digunakan peneliti adalah observasi deskriptif, dimana dalam tahap ini peneliti belum membawa masalah yang akan diteliti.

\section{b. Wawancara}

Pada penelitian ini, peneliti mengumpulkan data yang dibutuhkan dengan menggunakan teknik wawancara, yaitu teknik pengumpulan data melalui pertanyaan secara lisan kepada pihak informan (pengurus Koperasi Syariah As-Sakinah Sidoarjo). Pada saat mengajukan pertanyaan, peneliti dapat berbicara atau berhadapan secara langsung kepada pihak informan. Apabila tidak dapat bertemu secara langsung, peneliti bisa melakukan wawancara melalui alat komunikasi.

\section{c. Dokumentasi}

Adapun data yang didapat dalam proses penelitian yaitu dari buku RAT Koperasi Syariah As-Sakinah
Sidoarjo, hasil rekaman wawancara yang diperoleh, dan hasil foto saat melakukan penelitian.

\section{HASIL DAN PEMBAHASAN}

\section{Sekilas mengenai perkembangan Koperasi Syariah As-Sakinah Sidoarjo}

Berdasarkan hasil penelitian dari proses wawancara yang didapat, bahwa Koperasi As-Sakinah Sidoarjo merupakan sebuah lembaga Pimpinan Wilayah Aisyiyah (PWA) Jawa Timur. Dimana yang awalnya mempunyai program Bina Usaha Ekonomi Keluarga Aisyiyah. Tujuannya yaitu untuk dapat meningkatkan pemberdayaan ekonomi anggota Aisyiyah. Agar tujuan tersebut dapat tercapai salah satu cara dengan membentuk sebuah lembaga koperasi. Lembaga Koperasi dipandang sebagai wadah yang efektif bagi ibu-ibu Aisyiyah. Hal tersebut dapat kita buktikan dari adanya berbagai kegiatan simpan pinjam tepatnya dilingkungan ibu-ibu Aisyiyah. Kegiatan tersebut diadakan sebelum adanya tekait program Bina Usaha Ekonomi Keluarga Aisyiyah. Akan tetapi, dalam kegiatan tersebut masih belum terstruktur dan terorganisasi dengan baik. Agar proses kegiatan operasionalnya berjalan secara optimal, maka dibentuklah Koperasi As-Sakinah yang berbadan hukum nomor 28/BH/KDK.13/V/1999.

Awal didirikannya, Koperasi As-Sakinah Sidoarjo bertempat di jalan Diponegoro yang tergabung dengan Kantor Pimpinan Daerah Aisyiyah (PDA). Pertama kali didirikan, koperasi mempunyai bidang usaha dalam bentuk unit simpan pinjam serta unit toko. Terkait unit toko koperasi terus dikembangkan dengan baik walaupun dari segi tingkat penjualan bisa dikatakan masih rendah atau kurang optimal.

Dalam tahap peirode pertama Koperasi As-Sakinah dimulai pada tahun 1999 dengan jumlah anggota sekitar 25 orang. Dari 25 anggota tersebut memilih ibu Fatechah Munir sebagai ketua koperasi, dimana untuk masa jabatan sekitar 5 tahun. Aset koperasi pada waktu itu, kurang lebih mencapai 15.000.000. Perolehan aset tersebut didapatkan dari adanya simpanan pokok tiap anggota sebesar Rp 25.000, dan simpanan wajib tiap anggota sebesar Rp 1.000, sekaligus perolehan dana yang masih terkumpul dari kegiatan simpan pinjam ibuibu Aisyiyah sebelumnya.

Tepat pada tahun 2002, ibu Fatechah Munir mengundurkan diri sebagai ketua dan menunjuk ibu Nelly Asnifati sebagai pengganti ketua baru pada priode kedua hal ini bertepatan dengan adanya kegiatan RAT tahun buku 2002. Pada tahap kedua, anggota Koperasi As-Sakinah makin bertambah. Hingga sampai tahun 2004 jumlah anggota koperasi bertambah sebanyak 677 orang. Dalam anggota koperasi saat itu, bukan hanya 
sekedar dari ibu-ibu Aisyiyah saja melainkan juga terdapat dari masyarakat luar. Pada periode kedua, letak kantor koperasi berpindah mengikuti kantor PDA tepatnya di jalan Majapahit. Dengan kondisi tempat yang lebih luas, sangat membantu dalam proses mengembangkan unit toko. Adapun tujuan dari pengembangan unit toko, guna memenuhi kebutuhan anggota sekaligus dijadikan sebagai tempat pengulakan barang oleh anggota.

Sejak awal didirikan, lembaga koperasi ini sudah berpegang pada prinsip syariat islam. Tepatnya tahun 2004 sudah mulai memperkenalkan akad-akad yang sesuai dengan syariat islam kepada para anggota. Kendala koperasi saat itu, anggota yang masih merasa kesulitan dalam mengenal akad-akad pembiayaan, namun dalam hal ini pihak pengurus koperasi selalu memberikan edukasi secara bertahap. Sedangkan pada proses pembiayaan dengan pemberian pinjaman tanpa adanya sistem bunga baru dirintis sejak tahun 2004 . Hingga tahun 2010, semua proses pembiayaan di koperasi sudah sesuai dengan akad-akad islam, walaupun dalam proses pencatatan akuntansi yang belum sesuai dengan standar akuntansi syariah.

Perkembangan koperasi dalam membangun sebuah jaringan ditunjukkan dengan kerjasama koperasi dengan Dinas Koperasi sekaligus PKM baik di Kabupaten Sidoarjo maupun tingkat nasional. Koperasi As-Sakinah juga aktif dalam hal mengikuti kegiatan pelatihan serta mengadakan pelatian perkoperasian dari Dinas Koperasi dan PKM, Perguruan Tinggi, atau lembaga lain. Modal koperasi saat itu diperoleh dari kerjasama dengan Bank Syariah Mandiri serta Bank Syariah Bukopin.

\section{Analisis Penilaian Tingkat Kesehatan Koperasi Syariah As-Sakinah Sidoarjo}

Salah satu Koperasi Syariah yang aktif menjalankan bidang usaha dalam bentuk pembiayaan adalah Koperasi Syariah As-Sakinah Sidoarjo. Secara keseluruhan kinerja koperasi mengalami peningkatan sampai pertengahan tahun 2019 baik dalam bidang usaha, organisasi, administrasi keuangan, dan manajemen. Namun terdapat upaya untuk menjadi lebih baik sampai tahun selanjutnya, dikarenakan masih terdapat permasalahan yang muncul.

Dari permasalahan tersebut akan berdampak pada tingkat kesehatan koperasi. klasifikasi tinggi rendahnya tingkat kesehatan koperasi akan menentukan kelangsungan koperasi, apakah terus berkembang (active) atau justru tidak berkembang (non active) (Harto \& Amaliah, 2018). Dalam hal ini, lembaga koperasi perlu menjaga eksistensinya melalui peningkatan kinerja koperasi.

Kinerja merupakan hasil dari tanggung jawab perilaku kerja dalam menyelesaikan tugas atau amanah yang mampu dicapai dengan sebaik mungkin. Dan sekaligus didasarkan atas kecakapan atau keuletan, pengalaman, kesungguhan serta waktu (Adianto \& Sugiyanto, 2019).

Dengan kinerja koperasi yang baik akan memberikan pengaruh baik untuk perkembangan sebuah koperasi dimasa depan (Okfitasari \& Suyatno, 2018).

Untuk meningkatkan kinerja koperasi yang lebih optimal diperlukan adanya analisis penilaian tingkat kesehatan koperasi. Penilaian tingkat kesehatan Koperasi Syariah As Sakinah Sidoarjo dilakukan setiap 2 tahun sekali. Penilaian tingkat kesehatan lembaga koperasi sangat dianjurkan guna mengetahui perkembangan koperasi dan dapat dijadikan sebagai bahan perbaikan lembaga koperasi. Adapun Hasil penilaian tersebut dapat diliat pada tabel 1 berikut ini :

Tabel 1 : Hasil Penilaian Tingkat Kesehatan Koperasi Syariah As-Sakinah Sidoarjo Berdasarkan Permenkop dan UKM No.06/PER/M.KUKM/III/2008

\begin{tabular}{|c|l|c|c|}
\hline Poin & \multicolumn{1}{|c|}{ Variabel } & $\begin{array}{c}\text { Nilai } \\
\text { Maksimum }\end{array}$ & $\begin{array}{c}\text { Nilai } \\
\text { Diperoleh }\end{array}$ \\
\hline Point 1 & $\begin{array}{l}\text { Badan Usaha } \\
\text { Aktif }\end{array}$ & 95 & 81 \\
\hline Point 2 & $\begin{array}{l}\text { Kinerja Usaha } \\
\text { yang Makin } \\
\text { Sehat }\end{array}$ & 115 & 80 \\
\hline Point & $\begin{array}{l}\text { Kohesivitas dan } \\
\text { Partisipasi } \\
\text { Anggota }\end{array}$ & 105 & 72 \\
\hline Point 4 & $\begin{array}{l}\text { Orientasi Kepada } \\
\text { Pelayanan } \\
\text { Anggota }\end{array}$ & $\begin{array}{l}\text { Pelayanan } \\
\text { Kepada } \\
\text { Masyarakat }\end{array}$ & $\begin{array}{l}\text { Kontribusi } \\
\text { Koperasi } \\
\text { Terhadap } \\
\text { Pembangunan } \\
\text { Daerah }\end{array}$ \\
\hline Point & 20 & 20 \\
\hline Klasifikasi Nilai & Berkualitas \\
\hline
\end{tabular}

Sumber : Data Penilaian Koperasi Syariah AsSakinah Sidoarjo 
Adapun pembahasan terkait indikator yang mendukung hasil penilaian tingkat kesehatan Koperasi As-Sakinah Sidoarjo, antara lain :

\section{a. Aspek badan usaha aktif}

Terkait analisis yang telah dilakukan, pada aspek tersebut mendapatkan nilai perolehan skor 81 dari skor maksimum 95. Hasil perolehan skor tersebut diliat dari indikator penilaian mekanisme manajamen koperasi seperti penyelenggaraan rapat koperasi dalam satu tahun buku RAT, Koperasi As-Sakinah Sidoarjo mampu menyelenggarakan semua jenis rapat. Adapun kegiatan rapat yang diselenggarakan Koperasi AsSakinah yaitu rapat anggota, rapat pengurus dan pendamping, rapat pengurus dengan pengawas dan majelis ekonomi, sekaligus rapat anggota.

Indikator penilaian manajemen pengawasan, yang dilakukan selam 3 bulan sekali oleh bidang pengawas koperasi. dimana tujuanya untuk mengetahui kondisi koperasi sekaligus kinerja kepengurusan. Berdasarkan hasil pengawasan dalam bidang organisasi, administrasi, usaha maupun kinerja keuangan pengurus secara umum mengalami peningkatan, namun ada upaya untuk menjadi lebih baik kedepanya, dikarenakan masih terdapat permasalahan atau kendala yang ada.

Indikator penilaian kegiatan operasional yang masih beroperasi, Koperasi As-Sakinah Sidoarjo mempunyai 3 bidang usaha dimana kegiatan operasional atau bidang usahanya masih beroperasi dengan baik. Adapun diantaranya yaitu unit simpan pinjam, unit toko, dan unit kantin. Namun semasa pandemi, salah satu bidang usaha Koperasi As-Sakinah sudah tidak beroperasi dikarenakan tidak adanya laba atau keuntungan yang didapat.

Indikator penilaian tertib administrasi baik dari segi (organisasi, usaha, keuangan) yang terdapat dalam Koperasi As-Sakinah Sidoarjo. Pada organisasi, Koperasi As-Sakinah Sidoarjo sudah mempunyai buku pokok organisasi yang terdiri dari buku daftar anggota, daftar pengurus, daftar pengawas, daftar karyawan, simpanan anggota, notulen RAT, dan notulen rapat. Pada keuangan, kearsipan keuangan dan lainya sudah tersimpan dan tertata rapi di lemari Koperasi AsSakinah. Sedangkan pada usaha, terkait unit simpan pinjam pelaksanaanya sudah tertib, unit toko terkait bukti transaksi kurang lengkap dan belum disusun dengan rapi, terdapat buku persediaan tetapi kurang tertib dalam pencatatan keluar masuknya barang sehingga mengalami kesulitan dalam proses perhitungan persediaan.

Indikator penilaian keberadaan sistem informasi serta kemudahan dalam mengakses informasi, Indikator keberadaan RK dan RAPB dalam satu tahun buku yang disahkan secara langsung pada saat menjalankan rapat anggota.

\section{b. Aspek kinerja usaha yang sehat}

Terkait analisis yang telah dilakukan, pada aspek tersebut mendapatkan perolehan nilai skor 80 dari skor maksimum 115. Hasil perolehan skor tersebut diliat dari indikator penilaian struktur permodalan koperasi, terkait bidang permodalan pada Koperasi As-Sakinah. Modal koperasi terbagi menjadi 3 yaitu pertama modal sendiri, total modal sendiri pada koperasi mengalami kenaikan 1\% dimana tahun 2018 sebesar $\mathrm{Rp}$ 2.146.569.466 sedangkan di tahun 2019 menjadi Rp 2.157.952.466. kedua Untuk perkembangan total modal tidak tetap mengalami kenaikan 6\% dimana tahun 2018 sebesar Rp 4.176.960.575 sedangkan tahun 2019 menjadi Rp 4.420.531.038. dan terakhir, modal luar koperasi mengalami penurunan, dari tahun 2018 sebesar Rp 4.686.629.530 menjadi Rp 3.142.433.925 di tahun 2019.

Indikator penilaian kondisi keuangan koperasi yang diliat dari laporan neraca yang terdapat didalam buku RAT koperasi. Dalam laporan neraca Koperasi As-Sakinah Sidoarjo, aset koperasi mengalami penurunan. Pada tahun 2019, total aset koperasi sebesar $\mathrm{Rp}$ 11.031.922.317 sedangkan tahun 2018 sebesar $\mathrm{Rp}$ 13.189.181.262.

Indikator penilaian perkembangan SHU, perkembangan SHU Koperasi Syariah As-Sakinah Sidoarjo mengalami peningkatan. Pada tahun $2018 \mathrm{Rp}$ 90.000.000 kemudian tahun 2019 SHU koperasi meningkat sebesar Rp 110.000.000.

Indikator penilaian terkait kemampuan bersaing koperasi terhadap lembaga koperasi lainya, hal ini dapat diliat dari kelebihan atau ciri khas yang dimiliki oleh lembaga koperasi dari lembaga lainya. Sekaligus penilaian terkait produk (barang dan jasa) pada lembaga koperasi, apakah sudah sesuai dengan keinginan dan perilaku konsumen.

\section{c. Aspek kohesivitas dan partisipasi anggota}

Terkait analisis yang telah dilakukan, pada aspek tersebut mendapatkan perolehan nilai skor 72 dari skor maksimum 105. Hasil perolehan skor diliat dari indikator pertumbahan anggota. Perkembangan anggota Koperasi As-sakinah mengalami kenaikan. Tahun 2018 sebanyak 859 orang kemudian tahun 2019 menjadi 938 orang.

Indikator dari pertumbuhan peminjam, anggota yang meminjam dari tahun 2018 sebanyak 475 anggota sedangkan pada tahun 2019 sebanyak 544 anggota. Hal ini terliat penerima manfaat semakin meningkat. Sehingga harapan Koperasi As-Sakinah, dapat membantu anggota dalam mengatasi masalah keuangan atau keterbatasan modal. Agar berimplikasi positif pada salah satu sasaran penting yang ingin dicapai Koperasi 
As-Sakinah, yakni dapat meningakatkan volume usaha anggota dan menjauhkan masyarakat dari rentenir.

Indikator terkait hubungan pengurus, untuk hubungan pengurus dengan pengawas, anggota, karyawan, dan instansi dinilai menurun dari tahun sebelumnya, khususnya dengan pengawas silaturahmi dilakukan melalui acara formal maupun informal. Hubungan dengan pihak eksternal tetap baik dalam bentuk kerjasama permodalan, pendampingan, penelitian dan lain sebagainya.

Indikator penilaian lain dapat kita liat dari adanya keterkaitan anggota terhadap anggota lain sekaligus terhadap organisasi. Adanya sistem tanggung renteng dapat membantu anggota untuk berbagi risiko (risk sharing) apabila terjadi sebuah kendala atau permasalahan.

Indikator pengkaderan koperasi, pada Koperasi Syariah As-Sakinah proses penjaringan anggota baru yang mempunyai kualitas baik dan berpotensi akan tetap dimasukkan sebagai anggota. Sedangkan proses pengkaderan untuk calon pendamping dan pengurus lebih ditingkatkan sebagai regenerasi dan keberlanjutan Koperasi As-Sakinah dimasa depan.

\section{d. Aspek orientasi kepada pelayanan anggota}

Terkait analisis yang telah dilakukan, pada aspek tersebut mendapatkan perolehan nilai skor 122 dari skor maksimum 145. Indikator penilaianya diliat dari pelayanan dan pembinaan terhadap anggota. Untuk meningkatkan pelayanan dan pembinaan terhadap anggota Koperasi As-Sakinah Sidoarjo perlu adanya pendamping kelompok yang bertanggung jawab dan bertugas memberikan arahan, motivasi, edukasi, serta sosialisasi terhadap kelompok anggota As-Sakinah.

Terkait pendampingan anggota, pendamping pada Koperasi As-Sakinah Sidoarjo berjumlah 6 orang yaitu Luluk Farida, Ira Humairah, Siti Chulliyatul Jannah, Roudlatil Jannah, Sri Wahyuni, Yuli Arsanti serta 2 orang pengurus yang masih mendampingi kelompok bermasalah yaitu Susi Indrawati dan Nurdjannah. Adapun tugas dari para pendamping, untuk membantu pengurus dalam meningkatkan pembinaan terhadap anggota. Agar tugas yang diberikan kepada para pendamping dapat terarah dan berjalan dengan baik, maka dalam setiap akhir bulan dari pihak pendamping wajib menyetor berita informasi pendampingan pada pertemuan kegiatan rapat dengan pengurus.

Indikator realisasi pelaksanaan program pendidikan dan pelatihan, dalam pelaksanaan tersebut sudah tertuang pada realisasi program kerja koperasi yang sudah dijadwalkan masing-masing oleh pengurus. Adapun program pendidik diantaranya yaitu pelatian manajemen koperasi, diklat manajemen koperasi, pelatian pengembangan usaha koperasi berbasis online, sosialisasi perkoperasian bagi pelaku UMKM, dan sebagainya.

Indikator jumlah anggota sekaligus karyawan koperasi yang mengikuti pelatian. Pada karyawan Koperasi As-Sakinah, jumlah orang yang mengikuti pelatian sebanyak 6 orang dengan penempatan jabatan masing-masing. Dimana dalam penanggung jawab USP pelatihan koperasi sebanyak 4 kali, penanggung jawab gudang sebanyak 8 kali, penanggung jawab toko sebanyak 3 kali, staff administrasi USP sebanyak 1 kali, bagian sales dan display toko 2 kali, serta kasir toko majapahit sebanyak 3 kali.

\section{e. Aspek pelayanan terhadap masyarakat}

Aspek pelayanan terhadap masyarakat adalah berapa lama usaha yang dijalankan koperasi dapat menyerap tenaga kerja setempat, serta berapa banyak jumlah layanan koperasi yang dapat dinikmati oleh masyarakat umum termasuk dalam peran koperasi untuk membantu pemerintah dalam hal pengentasan kemiskinan masyarakat setempat (Parani, 2011).

Terkait analisis yang telah dilakukan, pada aspek tersebut mendapatkan perolehan nilai skor 20 dari skor maksimum 20. Adapun indikator penilaianya diliat dari jumlah layanan koperasi yang dapat dinikmati oleh masyarakat sekitar.

Koperasi As-Sakinah mempunyai bidang usaha dimana dalam masing-masing bidang tersebut terdapat petugas atau karyawan yang siap untuk melayani anggota sekaligus masyarakat setempat yang non anggota. Terkait indikator penilaian pelayanan dapat diliat dari sikap karyawan. Sikap pelayanan yang dimaksud adalah sikap yang sesuai dengan standart SOP yang sudah ditetapkan Koperasi As-Sakinah Menurut responan dari pengurus pada saat wawancara bahwa sikap yang diterapkan pada karyawan Koperasi As-Sakinah sangat sopan sehingga membuat anggota maupun non anggota merasa nyaman.

Indikator pada perhatian karyawan, adapun yang dimaksud yaitu perhatian yang dijanjikan untuk diberikan pada anggota dalam bentuk melayani dengan baik dan tulus serta memberikan sistem pelayanan yang menyenangkan anggota (Candra \& Oktafia, 2021). Berdasarkan respon dari pengurus Koperasi As-Sakinah bahwa perhatian yang diberikan kepada anggota juga baik dan memberikan kenyamanan.

Indikator terkait tindakan karyawan, berdasarkan respon dari pengurus Koperasi Syariah pada saat wawancara bahwa tindakan karyawan dalam melayani yaitu mengupayakan selalu tanggap pada saat anggota memerlukan bantuan misalnya terkait kendala atau permasalahan.

Indikator selanjutnya terkait tenaga kerja yang handal memang diperlukan dalam kemampuan memberikan pelayanan. Hal tersebut yang diterapkan 
oleh Koperasi As-Sakinah dengan cara merekrut para karyawan yang mempunyai keahlian dalam bidang pelayanan prima guna menjaga dan mempertahankan kualitas pelayanan di Koperasi As-Sakinah, karena segi kualitas dalam koperasi dapat dijadikan sebagai tolak ukur keberhasilan koperasi dalam melayani anggota (Nasuka, 2017).

Indikator terkait tanggung jawab, Kepercayaan angggota adalah hal yang penting bagi lembaga koperasi, sehingga Koperasi As-Sakinah mampu menerapkan rasa tanggungjawab yang besar terhadap anggota. Dengan adanya bukti rasa tanggungjawab yang besar dari karyawan, dapat memberikan kepuasan untuk para anggota atas pelayanan yang diberikan oleh Koperasi As-Sakinah Sidoarjo.

Indikator penilaian yang selanjutnya dapat diliat dari peran koperasi dalam mensejahterakan masyarakat. Adapun tujuan didirikan Koperasi AsSakinah yaitu untuk mengutamakan kepentingan anggota dan menjadi subyek dalam percaturan ekonomi bangsa. Untuk meningkatkan kesejahteraan anggota maupun masyarakat, membentuk bidang usaha seperti unit simpan pinjam, unit toko.

Untuk unit simpan pinjam, koperasi bergerak dalam bidang penghimpunan dana dari para anggota, dan kemudian akan disalurkan kembali dalam bentuk pinjaman kepada anggota. Sedangkan pada pembiayaan yaitu memberikan pembiayaan melalui pemberian pinjaman dana maupun fasilitas kepada para anggota yang membutuhkan modal untuk pengembangan sebuah usaha (Nutri \& Wahyuningrum, 2019).

Sedangkan unit toko, Tujuan Koperasi AsSakinah mengembangkan unit toko untuk memenuhi kebutuhan anggota dan non anggota (masyarakat) karena dari setiap anggota maupun masyarakat sangat membutuhkan kebutuhan sehari-hari. Saat itu, pengembangan unit toko tidak hanya untuk kebutuhan sehari-hari saja melainkan sebagai tempat anggota dalam proses pengulakan barang untuk kebutuhan usahanya.

\section{f. Kontribusi koperasi pada pembangunan daerah}

Dari aspek kontribusi terhadap pembangunan daerah merupakan proses ketaatan lembaga koperasi dalam membayar pajak sekaligus berbagai bentuk dukungan sumber daya terhadap kegiatan pembangunan daerah (Parani, 2011).

Terkait analisis yang telah dilakukan, pada aspek tersebut mendapatkan perolehan skor 12 dari skor maksimum 20. Adapun indikator terkait penilaianya yaitu dapat diliat dari ketepatan Koperasi As-Sakinah dalam membayar pajak.

\section{Dampak Penilaian Tingkat Kesehatan Koperasi As- Sakinah Sidoarjo}

Dari adanya penilaian tingkat kesehatan koperasi dapat memberikan dampak bagi kinerja koperasi. Dampak tersebut dapat diliat dari beberapa aspek berikut ini :

\section{a. Dampak bagi aspek badan usaha aktif}

Dari adanya penilaian tingkat kesehatan pada aspek ini, dapat memberikan dampak bagi kinerja koperasi. Kinerja koperasi bidang manajemen koperasi sudah dilaksanakan dengan baik. Hal ini dapat dibuktikan dengan adanya buku RAT koperasi terkait pengawasan dan pemeriksaan. Koperasi As-Sakinah yang mampu menyelenggarakan semua jenis rapat. Adapun kegiatan rapat yang diselenggarakan Koperasi As-Sakinah yaitu rapat anggota, rapat pengurus dan pendamping, rapat pengurus dengan pengawas dan majelis ekonomi, sekaligus rapat anggota.

Dampak lain dari penilaian tingkat kesehatan yaitu dapat memberikan gambaran terkait kinerja dari bidang administrasi. Dalam bidang administrasi koperasi sudah berjalan dengan baik, hal ini dapat dibuktikan dengan ketertiban yang sudah dilaksanakan Koperasi AsSakinah dalam bidang tersebut baik segi organisasi, usaha, serta keuangan. Misalnya terkait adanya buku pokok organisasi yang lengkap dimana terdiri dari buku daftar anggota, daftar pengurus, daftar pengawas, daftar karyawan, simpanan anggota, notulen RAT, dan notulen rapat. Sekaligus buku kearsipan keuangan dan lainya sudah tersimpan dan tertata rapi di lemari Koperasi AsSakinah.

Terkait kendala lain yang masih ada, dapat diliat dari bukti transaksi tidak tertata secara rapi, dan buku persediaan ada, tetapi kurang tertib dalam mencatat keluar masuknya barang sehingga seringkali mengalami kesulitan dalam perhitungan persediaan. Dengan adanya penilaian tingkat kesehatan memberikan dampak baik untuk proses perbaikan kinerja koperasi yang lebih optimal.

\section{b. Dampak bagi aspek kinerja usaha yang sehat}

Dari adanya penilaian tingkat kesehatanpada aspek ini, dapat memberikan dampak bagi kinerja keuangan koperasi. Hal ini dapat dibuktikan dari perkembangan bidang SHU dan permodalan Koperasi As-Sakinah yang mengalami peningkatan. Perkembangan SHU Koperasi As-Sakianah yang meningkat terliat dari SHU koperasi tahun $2018 \mathrm{Rp} 90.000 .000$ sedangkan tahun 2019 menjadi Rp 110.000.000. Sedangkan bidang permodalan Koperasi As Sakinah terbagi menjadi 2. Modal sendiri koperasi meningkat 1\%, tahun 2018 sebesar Rp 2.146.569.466 menjadi Rp 2.157.952.466 di tahun 2019. Dan modal luar koperasi meningkat $6 \%$, tahun 2018 sebesar $\mathrm{Rp} 4.176 .960 .575$ menjadi $\mathrm{Rp}$ 4.420.531.038 di tahun 2019 . 
Terkait kendala lain yang masih ada, dapat kita liat dari laporan neraca koperasi. Dari laporan neraca terkait aset koperasi mengalami penurunan, tahun 2019 total aset koperasi sebesar Rp 11.031.922.317 sedangkan tahun 2018 sebesar Rp 13.189.181.262. Dengan adanya penilaian tingkat kesehatan memberikan dampak yang baik untuk membantu memperbaiki atau membenahi kinerja keuangan koperasi yang masih belum optimal.

\section{c. Dampak bagi aspek kohesivitas dan partisipasi anggota}

Dari adanya penilaian tingkat kesehatan pada aspek ini, dapat memberikan dampak bagi kinerja koperasi dalam bidang organisasi, yang mengalami perkembangan baik. Hal ini dibuktikan dengan perkembangan keanggotaan Koperasi As-sakinah mengalami kenaikan. Tahun 2018 sebanyak 859 orang kemudian tahun 2019 menjadi 938 orang. Dengan demikian bisa dikatakan, bahwa kinerja pengurus atau karyawan Koperasi As-Sakinah mampu memberikan pelayanan yang baik.

Dampak lain dari penilaian tingkat kesehatan yaitu pertumbuhan peminjam anggota yang meningkat, anggota yang meminjam dari tahun 2018 sebanyak 475 anggota sedangkan pada tahun 2019 sebanyak 544 anggota. Hal ini dapat dikatakan bahwa penerima manfaat semakin meningkat. Sehingga harapan Koperasi As-Sakinah, dapat membantu anggota dalam mengatasi masalah keuangan atau keterbatasan modal. Agar berimplikasi positif pada salah satu sasaran penting yang ingin dicapai Koperasi As-Sakinah , yakni dapat meningakatkan volume usaha anggota dan menjauhkan masyarakat dari rentenir.

\section{d. Dampak bagi aspek orientasi kepada pelayanan anggota}

Dari adanya penilaian tingkat kesehatan pada aspek ini, dapat memberikan dampak bagi kinerja pengurus dalam meningkatkan pembinaan terhadap anggota, pendampingan terhadap angota, sekaligus pelatian dan pendidikan terhadap anggota. Dengan adanya pembinaan, pelatian, pendampingan tersebut bertujuan untuk mempertahankan anggota yang berkualitas. Karena pada dasarnya dalam Koperasi AsSakinah bukan hanya sekedar sebagai unit simpan pinjam maupun pembiayaan, melainkan sebagai wadah untuk pengembangan kemampuan anggota sekaligus.

Hal ini dibuktikan dengan adanya realisasi pelaksanaan program pendidikan dan pelatihan, dalam pelaksanaan tersebut sudah tertuang pada realisasi program kerja Koperasi As-Sakinah pada buku RAT koperasi, dimana yang sudah terdapat jadwal kegiatan masing-masing. Adapun program pendidikan diantaranya yaitu pelatian manajemen koperasi, diklat manajemen koperasi, pelatian pengembangan usaha koperasi berbasis online, sosialisasi perkoperasian bagi pelaku UMKM, dan sebagainya.

\section{e. Dampak bagi aspek pelayanan kepada masyarakat}

Dari adanya penilaian tingkat kesehatan pada aspek ini, dapat memberikan dampak bagi kinerja pengurus maupun karyawan. Dari hasil pengawasan maupun pemeriksaan kita dapat mengetahui pelayanan yang diberikan pengurus Koperasi As-Sakinah kepada anggota sudah berjalan dengan baik. Pelayanan tersebut terkait sikap dalam melayani, perhatian pengurus, tindakan pengurus dalam melayani, penampilan pengurus, kemampuan pengurus, serta rasa tanggung jawab pengurus koperasi.

Sedangkan terkait pelayanan yang diberikan karyawan koperasi terhadap non anggota (masyarakat) juga bisa dikatakan sudah berjalan dengan baik, hal ini dibuktikan adanya pengakuan secara langsung dari pengurus koperasi. Dimana pelayanan terkait sikap dalam melayani, tindakan, perhatian, kemampuan, sekaligus rasa tanggung jawab sudah berjalan dengan baik.

Dengan demikian, penilaian tingkat kesehatan dapat membantu koperasi untuk terus berbenah menjadi lebih baik, salah satunya dari segi kinerja koperasi. Penilaian tingkat kesehatan koperasi juga sangat diperlukan untuk mengetahui kondisi atau perkembangan sebuah koperasi. Tinggi rendahnya tingkat kesehatan koperasi akan menentukan kelangsungan koperasi, apakah terus berkembang (active) atau justru tidak berkembang (non active) (Harto \& Amaliah, 2018).

Secara keseluruhan, dapat dikatakan bahwa tingkat kesehatan Koperasi As-Sakinah Sidoarjo dari enam indikator dapat dikatakan baik walaupun masih terdapat pemasalahan atau kendala yang terjadi. Berdasarkan hasil klasifikasi penilaianya, Koperasi AsSakinah masuk dalam kategori penilaian yang berkualitas. Hasil tingkat pencapaian tersebut, dapat diliat dari kinerja Koperasi As-Sakinah dalam berbagai bidang. Dengan kinerja koperasi yang baik, sangat menentukan keberlangsungan koperasi, serta memberikan pengaruh baik untuk perkembangan sebuah koperasi dimasa depan (Okfitasari \& Suyatno, 2018).

\section{KESIMPULAN}

Dari hasil penelitian yang dilakukan oleh peneliti dan dipaparkan dalam bentuk naratif deskripsi pada bab sebelumnya, dimana peneliti dapat menarik kesimpulan. Pertama, berdasarkan perolehan data penelitian yang sudah didapat, bahwa secara keseluruhan tingkat kesehatan Koperasi As-Sakinah Sidoarjo dapat dikatakan baik, atau secara klasifikasi 
masuk dalam kategori berkualitas walaupun masih terdapat permasalahan yang ada. Dimana hasil perolehan tersebut dapat diliat dari 6 indikator yang sudah dianalisis. Adapun diantaranya yaitu meliputi badan usaha aktif, kinerja usaha yang sehat, kohesivitas dan partisipasi anggota, orientasi kepada pelayanan anggota, pelayanan terhadap masyarakat, dan kontribusi koperasi pada pembangunan daerah. Kedua, dari analisis tingkat kesehatan tersebut memberikan dampak pada kinerja koperasi. Dengan adanya analisis tingkat kesehatan mampu meningkatkan kinerja Koperasi As-Sakinah menjadi lebih baik dan terus berbenah guna meningkatkan perkembangan koperasi dimasa depan.

\section{UCAPAN TERIMA KASIH}

Penulis mengucapkan terima kasih kepada lembaga pendidikan yakni Universitas Muhammadiyah Sidoarjo yang memberikan atas ilmu pengetahuan sekaligus pengalaman yang sudah diberikan, serta kesempatan dan kemudahan yang diberikan ke saya. Terima kasih kepada Bapak Hidayatullah selaku Kepala Rektor Universitas Muhammadiyah Sidoarjo, Ibu Istiqomah selaku Dekan Fakultas Agama Islam, Ibu Fitri Nur Latifah selaku Ketua Program Studi Perbankan Syariah, serta Ibu Renny Oktafia selaku dosen pembimbing yang telah memberikan banyak arahan dan masukan pada penulisan artikel ini. Tidak lupa ucapan terima kasih dari saya kepada bapak editor dan para peer-reviewers yang sudah memberikan kesempatan sekaligus membantu proses untuk mempublikasikan artikel jurnal ilmiah ini. Terima kasih kepada pengurus Koperasi As-Sakinah yang sudah memberikan izin dan membantu saya dalam proses penelitian di lembaga koperasi syariah. Serta teman-teman yang sudah memberikan semangat dan motivasi kepada saya guna menyelesaikan artikel jurnal ilmiah ini.

\section{DAFTAR PUSTAKA}

Adianto, \& Sugiyanto. (2019). Pengaruh Pelatihan dan Pengembangan Kerja terhadap Kinerja Karyawan PT Bank Negara Indonesia (Persero) Tbk. Prosiding Seminar Nasional, 01(01), 499-509.

Buchori, N. S. (2012). Koperasi Syariah Teori dan Praktek. Banten: Pustaka Aufa Media.

Candra, A. W., \& Oktafia, R. (2021). Penerapan Manajemen Pelayanan Prima Untuk Peningkatan Kepuasan Calon Jamaah Haji dan Umrah di PT.
Mabruro Sidoarjo. Jurnal Ilmiah Ekonomi Islam, 7(01), 10-16.

Eindrias, T. D., \& Azizah, D. F. (2017). Analisa Tingkat Kesehatan Koperasi Simpan Pinjam Berdasarkan Peraturan Nomor : 06/PER/DEP.6/IV/2016 ( Studi Pada Koperasi Simpan Pinjam Bahagia Kota Kediri ). Jurnal Ad, 51(2), 135-140.

Harto, P. P., \& Amaliah, U. (2018). Penilaian Tingkat Kesehatan Koperasi Syariah Berdasarkan Peraturan Kementerian Koperasi Dan Ukm. Jurnal Ekonomi Dan Perbankan Syariah, 6(2), 5-26.

Listiadi, \& Hastuti, S. W. M. (2020). Kinerja Koperasi Berdasarkan Tingkat Kesehatan Koperasi Sesuai Permenkop. Dan UKM. Jurnal Ilmu Manajemen, 9(1), 40-47.

Marlina, R., \& Pratami, Y. Y. (2017). Koperasi Syariah Sebagai Solusi Penerapan Akad Syirkah Yang Sah. Jurnal Ekonomi Dan Keuangan Syariah, 1(2), 263-275.

Nasuka, M. (2017). Peningkatan Loyalitas Pelanggan Melalui Kepuasan Pelanggan Dengan Layanan Inti (Suatu Pendekatan Konsep Islamic Marketing). Jurnal Syari'ah Dan Hukum Diktum, 15(2), 191-205.

Nutri, A. F., \& Wahyuningrum, C. (2019). Penilaian Tingkat Kesehatan Koperasi Dari Aspek Likuiditas , Permodalan , Kemandirian Dan Pertumbuhan KSP Sahabat Setia SMAN 6 Kupang. Jurnal Ilmu Manajemen Dan Akuntansi, 7(1), 16-30.

Okfitasari, A., \& Suyatno, A. (2018). Analisis Kesehatan Koperasi Syariah dalam Upaya Meningkatkan Kinerja dan Pelayanan. Ilmiah Ekonomi Islam, 4(02), 103-115.

Oktafia, R. (2017). Percepatan Pertumbuhan Usaha Mikro, Kecil Dan Menengah (Umkm) Melalui Perkuatan Lembaga Keuangan Mikro Syariah (Lkms) Di Jawa Timur. Jurnal Ekonomi Islam, 3(1), 85-92.

Parani, S. B. D. (2011). Pemeringkatan Koperasi Di Provinsi Sulawesi Tengah. Jurnal Persepsi, 15(1).

Sofiani, T. (2014). Kontruksi Norma Hukum Koperasi Syariah Dalam Kerangka Sistem Hukum Koperasi Nasional. Jurnal Hukum Islam, 12(2).

Sugiyono. (2019). Metode Penelitian Kuantitatif,Kualitatif, Dan R\&D. Bandung: Alfabeta. 